\title{
Pendidikan Kristen Bagi Anak Balita (Sebuah Kajian Psikologis Dan Teologis)
}

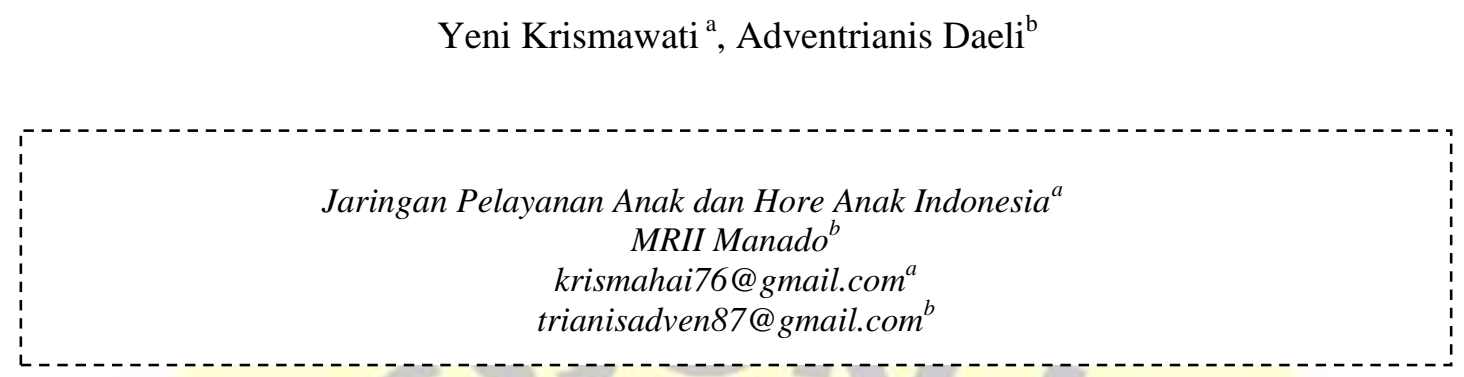

Abstrak

Penelitian ini memiliki tujuan untuk mengetahui teori dan praktik pendidikan Kristen bagi anak balita. Penelitian ini memakai metode kualitatif, pendekatan deskriptif dan teknik pengumpulan data melalui studi dokumen. Penulis mempelajari teori dan praktik pendidikan Kristen bagi anak balita secara luas dan mendalam untuk membangun konsep tentang pembelajaran yang sesuai dan bermakna bagi anak balita. Melalui penelitian ini ditemukan bahwa; pertama, kehidupan anak usia balita perlu diketahui dan dimengerti oleh mereka yang terlibat dalam dunia pelayanan anak agar proses pendidikannya efektif, apakah itu dalam konteks keluarga, sekolah dan gereja. Kedua, prinsip dan metode pembelajaran bagi pelayanan anak balita adalah khas disesuaikan dengan pertumbuhan dan perkembangan mereka secara fisik, sosial, emosi, iman, moral dan lainnya. Ketiga, peran pendidikan Kristen bagi pelayanan anak balita sangat signifikan dan turut menentukan kualitas mereka di mendatang supaya menjadi anak yang hidup sesuai dengan kehendak Tuhan.

Kata kunci : Pendidikan Kristen, Anak Balita, Keluarga, Sekolah, Gereja.

\section{PENDAHULUAN}

Satu negara tidak dapat mempertahankan dan melanjutkan pemerintahan tanpa anak, sebab anak merupakan generasi penerus / pemegang tongkat estafet di masa depan. Untuk mencapai target menghasilkan generasi penerus yang bermutu, maka anak penting diperlengkapi melalui pendidikan. Pendidikan yang dibutuhkan anak tidak terbatas kepada transfer pengetahuan melainkan bimbingan yang meliputi seluruh aspek kehidupan sehingga di kemudian hari anak mampu menjadi orang dewasa yang siap menjadi pemimpin, pendukung serta pengambil keputusan. Hal senada dikemukakan Nainggolan dan Janis bahwa tujuan pendidikan Kristen adalah bersifat holistik, bukan hanya sekadar menambah kuantitas pengetahuan dan pemahaman doktrinal, namun sekaligus untuk membentuk hidup yang berkualitas. Transformasi holistik berarti mencakup kognisi, afeksi, relasi, moral, karakter dan perilaku. (Nainggolan \& Janis, 2020, pp. 152-163)

Pendidikan yang diperlukan anak sebagai bekal masa depan tidak perlu menunggu sampai anak menjadi besar. Dalam psikologi perkembangan, setiap orang bertumbuh dari janin, anak-anak, dewasa sampai akhirnya memasuki usia lanjut. Christiani dalam buku Ajarlah Mereka Melakukan, menyatakan bahwa, perkembangan pada masa kanak-kanak khususnya dalam kurun waktu lima tahun pertama merupakan masa dimana seseorang mengalami perkembangan paling pesat dibanding masa dewasa. (Ismail, 2015, p. 129) Pendidikan Kristen dapat memanfaatkan kesempatan tersebut untuk melaksanakan tugasnya dalam mempersiapkan anak Balita sebagai generasi pewaris masa depan. 
Istilah balita merupakan sebutan baku yang sudah umum dipakai dalam bahasa Indonesia sehari-hari untuk menunjuk kepada anak usia lima tahun ke bawah. Para pendidik dan psikolog menjadikan usia balita sebagai masa yang sangat penting karena pada tahap tersebut anak memasuki tahun-tahun awal dalam menjalani kehidupan. Berbagai pengetahuan, pemahaman, perasaan, pikiran dan pengalaman anak, turut menentukan perkembangan semua dimensi seumur hidupnya. Hal senada dikemukakan oleh Daeli dan Nainggolan bahwa masa anak adalah masa emas dan terpenting. Mengapa? Karena masa anak-anak merupakan fondasi bangunan yang turut menentukan masa mendatang, masa yang paling diingat, daya menerima informasi tinggi, mencontoh sangat kuat, hati mereka masih polos, memiliki spontanitas, dan lainlain. Itulah sebabnya, mereka harus diajar untuk membenci dosa dan diupayakan agar mengasihi Tuhan dari sejak kecilnya. (Daeli \& Nainggolan, 2020, pp. 45-57)

Seperti yang dikemukakan Fung \& Ming, "Masa-masa rentan dari kehidupan seorang anak ialah berada pada enam (6) tahun pertama dalam kehidupannya, yang di dalamnya ialah masa bayi, anak kecil dan anak usia pra sekolah”. (Fung \& Ming, 2003, p. 2) Berbagai perubahan yang terjadi pada masa tersebut menjadi dasar bagi perkembangan anak dikemudian hari. Bahkan untuk melihat masalah-masalah yang dihadapi seseorang pada usia dewasa, dapat ditelusuri dari kehidupannya pada masa anak.

Artikel ini berupaya memaparkan beberapa kasus yang ditemukan dalam pelayanan berkaitan dengan kehidupan anak Balita. Masalah-masalah tersebut berangkat dari fakta dalam kehidupan rumah tangga Kristen, gereja serta lembaga pendidikan formal, dimana terdapat banyak pandangan yang salah dalam menilai anak Balita. Pandangan tersebut mempengaruhi pola pendidikan yang diterapkan sehingga orangtua maupun guru sebagai pengasuh serta pendidik anak, gagal membentuk dan mempersiapkan anak sebagai pribadi yang dapat diharapkan sebagai generasi penerus. Berikut beberapa masalah yang secara umum banyak dijumpai dalam pelayanan baik di keluarga, gereja maupun sekolah:

Pertama, contoh kasus dalam keluarga. Pada umumnya keluarga muda yang masih mementingkan karier untuk memenuhi berbagai target dalam rumah tangga, mengabaikan perhatian kepada anak mereka yang masih Balita. Suami sibuk mencari uang sementara itu dengan alasan mencari penghasilan tambahan isteri pun bekerja. Berhasil mencukupi kebutuhan anak serta menyediakan berbagai fasilitas seperti mainan, rumah yang nyaman maupun sekolah yang bermutu dianggap telah menggantikan kebutuhan anak akan perhatian dan kasih sayang orangtua. Sementara itu fungsi orangtua sebagai pengasuh terpenting dalam kehidupan anak digantikan oleh Babby Sitter. Alasan klise yang biasa terdengar ialah para ibu muda merasa berat meninggalkan pekerjaan mereka yang semakin menjanjikan. "Semua yang kami lakukan kan untuk masa depan anak, sayang kalau pekerjaan itu dilepas begitu saja," demikian pendapat umum para wanita karier. Akibatnya, pendidikan terabaikan dan anaklah yang menjadi korban.

Sepasang suami isteri di Jakarta yang keduanya berprofesi sebagai dokter, menyesali keputusan yang diambil anaknya untuk berpindah agama. Menurut pengakuan mereka, sejak bayi hingga Taman Kanak-kanak anak lelaki mereka diasuh oleh seorang pembantu yang beragama Islam. Karena kedua orangtua sibuk dengan pekerjaan di Rumah Sakit serta praktik di rumah, maka urusan anak sebagian besar dialihfungsikan kepada pembantu tersebut. Kedekatan anak dengan pembantu sama sekali tidak mendatangkan kecurigaan orangtua sampai akhirnya pada saat anak mereka 
memasuki bangku SMP, ia menyatakan bahwa Allah yang benar ditemukan dalam agama Islam. Melalui berbagai penelusuran, ternyata pada masa Balita anak tersebut hampir selalu menyaksikan pembantunya menjalankan shalat dan mendengarkan shalat mahgrip yang diputar di televisi setiap sore. Anak bertanya tentang Allah dan pembantu memberikan penjelasan menurut konsep yang ia yakini. Demikianlah relasi antara anak dan pembantu yang berlangsung sekitar lima tahun membawa dampak yang sangat mendukakan orangtua. Apa gunanya memperoleh harta dan kesuksesan tetapi kehilangan anak?.

Kedua, contoh kasus Di Gereja. Dalam pembinaan kepada para guru Sekolah Minggu dari berbagai gereja (GKI, HKBP, GBI, GBKP), keluhan yang seringkali muncul ialah bagaimana menertibkan anak kelas Balita selama kebaktian berlangsung. Para Guru Balita mengeluh karena banyak anak yang berjalan, bermain bahkan tidurtiduran saat kebaktian dilaksanakan. Menurut pengakuan para guru sikap tersebut membuyarkan konsentrasi ketika guru sedang memimpin pujian atau bercerita. Melihat kenyataan tersebut guru merasa gagal menjalankan tugasnya karena tidak berhasil menertibkan anak dan membuat mereka menjadi anak yang sopan, diam dan tenang selama beribadah.

Sedangkan keluhan orangtua berkaitan dengan anak-anak mereka yang masih Balita ialah keaktifan anak mengakibatkan terganggunya kenyamanan orang lain dalam mengikuti kebaktian umum. Jika anak diikutsertakan dalam Sekolah Minggu, tidak ada orang yang mendampingi anak sementara itu orangtua sendiri juga menghendaki kehadirannya dalam kebaktian umum. Masalah yang sering terjadi di gereja ialah pelaksanaan Sekolah Minggu yang bertepatan waktunya dengan kebaktian umum, dilaksanakan bukan untuk memenuhi kebutuhan rohani anak melainkan sebagai solusi yang diputuskan gereja supaya anak tidak menimbulkan keributan selama kaum dewasa beribadah. Akibatnya, anak menjadi korban karena Sekolah Minggu dibentuk sekedar pelengkap dengan tempat dan guru yang "asal ada".

Ketiga, contoh kasus di Sekolah. Setiap orangtua mengharap anak-anaknya dapat mengikuti pendidikan di institusi yang tidak hanya memperlengkapi anak dari segi pengetahuan melainkan juga yang mendukung pertumbuhan iman anak. Itu sebabnya bagi orangtua Kristen, menyekolahkan anak di bawah yayasan Kristen pada umumnya menjadi pilihan pertama demi keamanan perkembangan kerohanian anak. Tetapi masalahnya, tidak semua orangtua sanggup menyekolahkan anaknya di sekolah Kristen mengingat biaya operasionalnya yang cukup besar.

Nia adalah seorang anak berusia 4 tahun yang mengikuti pendidikan di Taman Kanak-kanak yang dikelola oleh yayasan BI di Jakarta. Meskipun sudah punya nama, hanya sedikit orangtua Kristen yang menyekolahkan anaknya ke TK tersebut mengingat sekolah BI dikenal bernuansa Islam. Karena dekat dengan rumah nenek, maka Nia disekolahkan di TK tersebut. Suatu hari sepulang dari sekolah Nia menangis keras-keras dan tidak mau lagi sekolah karena teman-teman mengejeknya dengan mengatakan bahwa Tuhan Yesus yang disembah oleh Nia mati disalib karena nakal. Nia yang sering kali mengikuti salah satu pembinaan rohani anak yang diselenggarakan PEA Jakarta dengan nama Pondok Gembira, telah mendengar bahwa Tuhan Yesus mati disalib dan bangkit bukan karena Ia berdosa melainkan untuk memikul dosa setiap orang termasuk anak-anak. Menurut penuturan mamanya Nia, anak tersebut yakin bahwa ucapan temantemannya salah. Tetapi karena merasa tidak punya teman yang membelanya, Nia takut dan malu dengan teman-temannya. Syukurlah bahwa mamanya cepat tanggap dengan peristiwa tersebut, sehingga ia berusaha meneguhkan keyakinan Nia tentang Tuhan 
Yesus dan memutuskan untuk mendampingi anaknya sekolah sekalipun menunda untuk tidak bekerja.

Masih cukup banyak kasus lain yang dapat diangkat sebagai contoh untuk melihat begitu pentingnya anak usia Balita menerima perhatian khusus dengan mempertimbangkan bahwa lima tahun pertama menjadi penentu bagi seluruh kehidupannya. Perlu diingat bahwa sebagai pribadi yang berusaha mengenal kehidupan, anak Balita memiliki banyak keterbatasan. Itu sebabnya anak Balita masih sangat bergantung kepada peran orang-orang terdekat dalam kehidupannya yang tidak hanya berfungsi sebagai pembimbing melainkan juga sebagai pelindung. Peran orang lain sebagai pelindung semakin dibutuhkan mengingat angka kejahatan terhadap anak Balita termasuk di Indonesia semakinmeningkat.

Menyimak berbagai kasus yang terjadi pada anak usia Balita, penting untuk dipikirkan bagaimana caranya agar berbagai permasalahan tersebut dapat teratasi atau adanya upaya sadar dan terencana untuk meminimalkan masalah-masalah yang ada dalam pelayanan anak Balita. Pendidikan Kristen perlu merumuskan sebuah teori serta merancangkan solusi praktis untuk menolong para pendidik dalam melaksanakan pelayanannya di kalangan anak Balita.

Guna membatasi serta mengarahkan penelitian selanjutnya, maka yang menjadi pertanyaan penuntun dalam penelitian ini adalah; (a) Bagaimana kehidupan anak usia Balita? (b) Apa prinsip dan metode pembelajaran bagi pelayanan anak Balita? (c) Bagaimana peran Pendidikan Kristen bagi pelayanan anak Balita?. Dengan memperhatikan pokok permasalahan di atas, maka penulisan makalah ini mempunyai tiga tujuan. Pertama, menjelaskan kehidupan anak usia lima tahun ke bawah dengan segala perkembangan yang dialami. Kedua, mengemukakan prinsip dan metode yang tepat bagi pelayanan anak Balita. Dan ketiga, mengusulkan sebuah pendekatan Pendidikan Kristen atas dasar Alkitab dan Teologi guna meningkatkan kualitas pelayanan anak Balita.

\section{METODE}

Metode penelitian yang dipilih dalam artikel ini adalah metode kualitatif yang bersifat deskriptif, dengan studi dokumen (kepustakaan) dari perspektif psikologis, biblis dan teologis. Untuk mengetahui dan memahami pendidikan Kristen bagi anak Balita maka pemanfaatan literatur terkait seperti laporan penelitian, media massa, media elektronik, jurnal, artikel dan lainnya akan memberikan deskripsi, selain juga untuk mengetahui kehidupan anak usia lima tahun ke bawah dengan segala perkembangan yang dialami, mengemukakan prinsip dan metode yang tepat bagi pelayanan anak Balita, dan sebuah pendekatan Pendidikan Kristen atas dasar Alkitab dan Teologi guna meningkatkan kualitas pelayanan anak Balita.

Penelitian ini memanfaatkan buku-buku monograf, referensi, teks, dan jurnal ilmiah. Hal senada dikemukakan oleh Nainggolan dan Labobar (2021: 113-125) bahwa pengumpulan data dilaksanakan secara bertahap dan melalui studi dokumen oleh peneliti dengan melakukan penelusuran dan penggalian terhadap jurnal, laporan penelitian, dan buku-buku Pendidikan Kristen yang terkait dengan topik yang sedang diteliti. (Nainggolan \& Labobar, 2021, pp. 113-125) Hal ini bermanfaat untuk membangun konsep tentang pendidikan Kristen bagi balita. Jika selanjutnya ada data yang kurang relevan atau tidak sesuai, peneliti masih bisa menggunakan data utama dan pendukung lain yang ada. 
Data yang terkumpul akan dianalisis oleh penulis. Konsep-konsep dianalisis dengan cara memperhatikan keterkaitan, kesamaan, dan kesesuaian dengan topik penelitian. Analisis data dilaksanakan secara induktif, melalui beberapa tahapan yakni, reduksi data, penyajian data, verifikasi dan penarikan kesimpulan. (Sugiyono, 2011, pp.339-343) Selanjutnya, penulis akan menguraikan temuan penelitian, yakni pendidikan Kristen bagi anak Balita. Setelah mendiskusikan hasil temuan, maka penulis akan akan menyimpulkan seluruh rangkaian penelitian. Akhirnya penulis juga menguraikan ucapan terima kasih bagi mereka yang mendukung penyelesaian penelitian ini.

\section{HASIL DAN PEMBAHASAN KEHIDUPAN ANAK BALITA}

Dalam rangka memperoleh gambaran secara umum mengenai anak balita, penting dan mendesak menyimak tahap-tahap pertumbuhan dan perkembangan yang mereka alami dan rasakan. Elia yang merupakan seorang tokoh Pendidikan anak mengklasifikasikan perkembangan anak dalam beberapa tingkatan. Perkembangan anak balita tidak dapat dilepaskan dari keberadaan anak semasa masih janin dalam kandungan ibunya. Selanjutnya anak menjalani masa bayi antara usia nol ampai dengan satu tahun (0-1) tahun. Tahap selanjutnya lebih sering dikenal dengan masa pra sekolah dibagi dalam dua tahap. Tahap kesatu ketika anak berusia dua sampai dengan tiga (2-3) tahun dan tahap kedua usia empat sampai dengan lima (4-5) tahun. (Elia, 1994, p.1) Berikut tahapan pertumbuhan dan perkembangan penting yang dialami anak balita; Perkembangan Masa Janin

Ketika anak dikandung oleh ibunya disebut dengan masa janin. Dalam hal ini anak balita sangat dipengaruhi oleh pelbagai pengalaman yang dialami ibu baik yang membawa sukacita atau sebaliknya. Apabila ibu tidak memperoleh gizi yang seimbang atau pola hidup yang sehat selama mengandung, maka di masa mendatang anak berpotensi mengalami gangguan kesehatan dan keterbelakangan intelek. Jikalau ibu banyak mengalami tekanan batin, maka anak yang lahir akan bertumbuh dan berkembang menjadi pribadi yang berkepribadian tidak stabil. Di samping eksistensi ibu, hubungan harmonis ayah dan ibu mempunyai peran penting dalam menghadirkan rasa aman bagi kelangsungan pertumbuhan dan perkembangan janin. Gunarsa mengistilahkan ini sebagai masa pralahir (sebelum lahir), merupakan masa yang sangat signifikan bagi terbentuknya potensi-potensi (bakat, talenta, dan lainnya) anak yang akan berpengaruh pada pertumbuhan dan perkembangan selanjutnya. (Gunarsa, 2000, p.7)

\section{Perkembangan Masa Bayi (0-1 Tahun)}

Perkembangan yang dihadapi anak pada masa bayi mengindikasikan perubahan / transformasi yang cepat sekali diketahui dan dipahami. Faktor yang menyebabkannya adalah perubahan dominan yang dialami dan dirasakan anak terjadi pada segi fisik / jasmaninya. Namun anak juga mulai beradaptasi dengan pelbagai perkembangan lain dalam dimensi psikomotorik, intelegensi, kepribadian, social dan lainnya. Fung \& Ming mengemukakan bahwa pada dasarnya perkembangan fisik nampak jelas melalui bertambahnya ukuran panjang dan berat badan bayi. Perkembangan fisik tersebut erat hubungannya dengan kematangan sistem syaraf. (Fung \& Ming, p.28) Sedangkan Gunarsa memaparkan bahwa perkembangan gerak-gerik anak masih merupakan motorik kasar. "Perkembangan motorik nampak dari adanya respon bayi terhadap 
rangsang berupa gerakan seluruh tubuh dan refleks-refleks". (Gunarsa, 2000, p.9) Anak secara bertahap mulai bergerak, misalnya dengan menggerakkan tangan, kaki, kepala, tengkurap (merangkak, berdiri, berjalan), memegang, meloncat dan berlari.

Perkembangan kognitif makin nampak jelas pada usia 4-6 minggu dimana bayi telah memiliki kemampuan untuk membalas arah perhatian kepada hanya satu bagian kecil dari apa yang dilihat. Kemampuan berpikir anak dilandasi rasa ingin tahu. Piaget memaparkan bahwa pada masa bayi anak berupaya memahami dunia luar lewat panca indera serta organ-organ tubuh lainnya. Kompetensi kognitif anak juga terlatih lewat pelbagai alat permainan. (Willhoit, et. al, 1995, p.53) Anak juga mengalami perkembangan dari dimensi kepribadiannya. Anak telah mampu menyatakan emosinya dengan cara marah, menangis, takut dan lainnya. Kemampuan anak untuk bersosialisasi terlatih melalui interaksi anak dan ibu sebagai orang terdekat yang sudah mempunyai ikatan batin lewat proses menyusui.

\section{Perkembangan pada Usia 2-3 Tahun}

Usia 2-3 tahun disebut juga masa kanak-kanak tahap awal. Anak semakin terampil beradaptasi dengan perkembangan yang dialaminya. Pertumbuhan badan lebih stabil, tidak secepat pada tahap sebelumnya. Anak juga semakin efektif dalam mengontrol proses pembuangan air besar dan air kecil. Pertumbuhan anggota tubuh pada bagian kepala pada umumnya lebih intensif dibandingkan anggota tubuh lainnya.

Dari aspek perkembangan motorik, anak sudah mampu mencoret-coret dengan alat tulis. Perkembangan kognitif yang dialami anak semakin nampak jelas lewat bertambahnya perbendaharaan kata yang dikuasai dimana anak dapat mengucapkan dengan lafal ucapan yang semakin jelas. Pada usia 2-3 tahun anak juga mulai belajar mengerti moral untuk mempertimbangkan pilihan antara benar atau salah, baik dan buruk atau tepat dan tidak tepat. Konsep moral yang dipahami anak pada usia ini masih sangat dipengaruhi oleh hadiah dan hukuman (reward and punishment) yang diperoleh anak. Contohnya, anak akan mengetahui bahwa saling berebut mainan merupakan tindakan dan sikap yang salah jikalau mereka dihukum. Perkembangan yang tidak kalah penting pada usia ini ialah spritualitas anak. Bagaimana seorang anak belajar mengenal Allah, hidup dalam rencana dan kehendak-Nya sangat ditentukan oleh apa yang diinderai dari manusia yang ada di lingkungannya. Misalnya, konsepnya mengenai Tuhan sangat dipengaruhi oleh sikap dan tindakan ayah bagi anggota keluarganya, karena melambangkan pribadi yang berwewenang / berotoritas.

\section{Perkembangan Anak Usia 4-5 Tahun}

Perkembangan fisik yang terjadi pada masa 4-5 tahun ialah terbentuknya penguasaan diri yang lebih baik dimana anak mampu mengontrol diri saat mana untuk membuang air besar atau kecil. Tinggi rata-rata $80-120 \mathrm{~cm}$ dan berat $15-22 \mathrm{~kg}$. Anak sudah mampu berlari, melompat, memanjat, bermain bola, menari bahkan memainkan alat musik. Dalam perkembangan kognitif, anak mampu menulis dan mengimajinasikan arti kata-kata yang sederhana terhitung 1-50. Sudah dapat melakukan simbolisasi bagi huruf, angka dan keruangan benda. Anak juga sudah dapat berpikir konkrit dan mampu berkonsentrasi.

Sekalipun masih egosentris anak dapat diajak untuk memahami orang lain. Ini merupakan tahap perkembangan kepribadian anak pada usia ini. Pengenalan terhadap jenis kelamin perlu disampaikan mengingat peran figur dari ayah dan ibu memampukan anak mempunyai kejelasan mengenai identitas dirinya. Salah satu konflik yang dialami 
adalah antara inisiatif sebagai perwujudan dari hasrat ingin tahu, dengan rasa takut bahwa apa yang diperbuatnya adalah sebuah kesalahan.

\section{PRINSIP-PRINSIP PEMBELAJARAN ANAK BALITA}

Berkaitan dengan kehidupan anak pada usia Balita, seorang perintis dalam pendidikan anak-anak pra sekolah, Maria Montessori mengungkapkan, "Mengapa seorang anak harus menunggu sampai berumur enam tahun untuk memulai pekerjaan hidupnya. Usia enam tahun itu adalah sangat terlambat". (Penginjilan Terarah, p.10) Ungkapan tersebut menunjukkan betapa pentingnya usia Balita mendapatkan perhatian yang serius. Patut disayangkan apabila pendidikan baru diberikan kepada seorang anak setelah melewati usia balita.

\section{Pendidikan Balita, Fokus Agama-agama Besar dan Komunis}

Menyimak prinsip pendidikan yang dilaksanakan oleh agama-agama besar serta faham Komunis yang berhasil menanamkan ideologinya ke berbagai penjuru dunia, anak usia Balita menjadi fokus utama dalam obyek pendidikan. W.S. Heath menjelaskan dalam Pembentukan Watak dan Tata Nilai (1999) bahwa keberhasilan Komunis di Cina sejak tahun 1949, di Kuba, Rusia maupun negara-negara lain yang dikuasai terletak pada penanaman ideologi melalui pendidikan anak-anak. Komunisme mempunyai rencana-rencana jangka panjang dimana mereka membangun untuk masa depan. Mereka sabar menunggu hasil melalui pengajaran dan penyusupan doktrin politik komunisme yang disampaikan melalui pendidikan. Dalam hal ini metode pendekatan yang diterapkan komunis sejalan dengan prinsip pendidikan Pazmino bahwa pendidikan harus mempunyai tujuan yang jelas bukan hanya untuk kekinian tetapi juga masa mendatang. (Pazmino, 2018, p.38)

Contoh metode pendidikan melalui tanya jawab yang dilakukan komunis untuk menghapuskan kepercayaan terhadap Tuhan dalam kehidupan seorang anak di Taman Kanak-kanak misalnya melalui dialog sebagai berikut dalam Teologi Penginjilan Anak (1999):

Pendidik : :Apakah kamu percaya bahwa Tuhan itu ada?"

Anak : "Ya, saya percaya."

Pendidik : "Bagaimana kamu tahu, tunjukkan dimana Tuhan itu!"

Anak : (Bingung, tidak bisa menjelaskan)

Pendidik : "Coba kamu sekarang berdoa untuk meminta permen kepada Tuhan"

(Anak berdoa sampai selesai tetapi permen tidak ada)

"Coba kamu meminta permen kepada saya dan saya dapat memberimu".

Metode dialog di atas menjadi salah satu sarana efektif untuk meyakinkan anak tentang sebuah konsep. Pola ini dapat diterapkan dalam Pendidikan Kristen bagi anak Balita sebagai salah satu materi kurikulum seperti yang terdapat dalam pendekatan Liberation yang dikemukakan Seymour \& Miller. (Seymour \& Miller, 1982, p.32)

Konsep beberapa agama besar dalam menilai pentingnya pendidikan anak demi kelangsungan masa depan, mendorong agama tersebut giat menanamkan ajarannya sehingga menyebarluas serta tertanam kuat dalam kehidupan seseorang. Yudaisme berhasil memelihara keutuhan agamanya karena secara terus-menerus mereka melaksanakan ajaran iman seperti yang diperintahkan dalam Ulangan 6:4-9. Begitu juga yang terjadi dalam pola penanaman doktrin agama Islam. Sebelum mengenal sekolah formal, anak-anak dimasukkan dalam kelompok pengajian Al'Quran dimana melaluinya 
anak diindoktrinasi untuk memegang Islam sebagai satu-satunya agama yang benar. Sedangkan agama Katolik dikenal sebagai pelopor dalam menyelenggarakan sistem pendidikan melalui pelatihan dan didikan intensif dalam sekolah-sekolah. H. Raymond Florence dalam Penginjilan Terarah (p.13) mengutip prinsip para pendidik Katolik yang mengatakan, "Berilah kami seorang anak sampai ia berumur 7 tahun, dan ia tidak akan meninggalkan kami lagi". Dalam pernyataan tersebut, jelaslah bahwa usia di bawah tujuh tahun, termasuk Balita tentunya merupakan masa yang sangat baik untuk mendidik seorang anak karena apa yang anak terima membawa pengaruh besar bagi kehidupannya di masa dewasa.

\section{Alkitab Sebagai Dasar Pendidikan Anak Balita}

Anthony menanggapi pentingnya fondasi Alkitab dalam dunia pendidikan anak, disebabkan Tuhan berkehendak memberikan petunjuk mengenai cara memperhatikan, mengasuh, memelihara dan membesarkan anak. Baik PL maupun PB memberikan gambaran tentang perhatian bagi kebutuhan fisik, emosi maupun kerohanian anak. (Anthony, 2001, p.22) Alkitab merupakan landasan utama mendeskripsikan bahwa pendidikan anak sangat penting. Hal ini nampak jelas ketika Tuhan dalam Perjanjian Lama memerintahkan bangsa Israel untuk mengasihi Tuhan dan mendidik anak-anak mereka agar mengenal Tuhan (U1. 6:4-6). Demikian juga Salomo menjelaskan pelbagai wejangan berkenaan dengan pendidikan yang dilakukan oleh orangtua sangat bermanfaat bagi kehidupan anak untuk hidup di masa kini maupun masa mendatang anak dan orangtua (Ams. 1:8; 3:1-2; 4:13; 8:33; 22:6).

Dalam PB, Yesus memandang bahwa kebutuhan anak akan pendidikan rohani. Itu sebabnya Yesus mengundang setiap anak untuk dapat datang kepada-Nya (Mat. 19:14). Di mata Yesus anak-anak sangat berharga, sama seperti orang dewasa. Rasul Paulus juga berpesan kepada beberapa jemaat mengenai pentingnya pendidikan anak sebagai tanggung jawab orangtua (Ef. 6:4; Kol. 3:21).

\section{Dasar Teologi}

Pendidikan Kristen bagi anak balita memiliki fondasi teologi yang kuat dan jelas. Hal ini dikarenakan anak merupakan bagian dari keluarga dimana rencana Allah dinyatakan. Sejak pendelegasian Tuhan kepada Adam (Kej. 1:28) maupun pemanggilan khusus Abraham (Kej. 12:3), Tuhan menetapkan dan menjadikan keluarga sebagai wakil-Nya untuk mendemonstrasikan kasih Allah kepada dunia. Setiap anak yang lahir dalam keluarga orang Kristen penting mendapat didikan supaya terbentuk anak bermutu yang dapat menjadi berkat bagi keluarga lain yang belum percaya. Anak memiliki kedudukan yang sama dengan anak balita. Tuhan Yesus memandang anak sebagai penerima berkat Allah.

Pertama, semua anak adalah orang berdosa. Kedudukan anak di mata Tuhan, layaknya seperti semua orang dewasa yakni sebagai orang yang telah kehilangan kemuliaan Allah, pendosa (Rom. 3:23). Pelanggaran Adam terhadap perintah Allah ti Taman Eden (Kej. 2 dan 3) membawa semua manusia, yang di dalamnya anak-anak menjadi berdosa (Rm. 5:18). Ini yang sering disebut dengan dosa warisan. Sejak seorang anak dikandung oleh ibunya, ia merupakan manusia berdosa (Maz. 51:7) yang selanjutnya akan memperoleh penghukuman (Rom. 6:23). Yesus sendiri menyebut anak sebagai bagian dari jiwa yang terhilang (Mat. 18:12-13). Bahkan Yesus memerintahkan agar murid-murid-Nya untuk tidak menghalang-halangi anak kecil datang kepada-Nya. 
Kedua, peran Roh Kudus bagi anak balita. Jikalau seseorang termasuk anak balita masih menjadi manusia duniawi, hidup mengikuti keinginan daging sama seperti semua orang pada umumnya, maka tujuan Pendidikan Kristen belum tercapai karena anak tidak dapat mengalami transformasi yang sebenarnya meskipun telah mendapat didikan (1 Kor. 2:14). Anak sanggup untuk menjadi baik berdasarkan Pendidikan Kristen menurut standar Allah, hanya terjadi jika anak balita telah menerima Yesus sebagai Tuhan dan Juruselamat secara pribadi. Setelah status anak berubah yaitu sebagai anak Allah yang didiami Roh Kudus, maka anak dimampukan untuk melakukan perintah Tuhan (Rom. 8:9b). Hanya Roh Kuduslah yang mampu menyadarkan anak akan dosa, kebenaran dan penghakiman (Yoh. 16:18). Pazmino dalam God Our Teacher (2001, p.101) menyebut kedudukan Roh Kudus sama dengan Yesus, Roh Kudus adalah Guru yang memimpin setiap orang pada kebenaran menuju kehendak Allah.

Ketiga, anak balita berpotensi untuk percaya kepada Yesus. Cara untuk menjadikan seorang anak balita menjadi milik Tuhan adalah dengan membimbingnya supaya percaya kepada Yesus sebagai Tuhan dan Juruselamat secara pribadi. Fakta membuktikan bahwa beberapa gereja, yang di dalamnya para pemimpin rohani memiliki pandangan yang menentang penginjilan anak. Mereka berpendapat bahwa anak belum mengerti kebenaran yang disampaikan atau keputusan anak pada usia balita belum dapat dipertanggungjawabkan sebagai keputusan yang pasti. Menanggapi pelbagai pandangan tersebut, gereja penting menyimak dan memahami pendapat Henkel dalam Penginjilan Terarah (p.10) sebagai pendidik Kristen yang mengemukakan bahwa, "Pendidik-pendidik agama biasanya mengambil patokan-patokan mereka dari pendidikan sekuler, sebenarnya hal ini tidak layak."

Ajaran para tokoh pendidikan Kristen dan pandangan Yesus sendiri menjelaskan bahwa anak balita mempunyai potensi untuk mengerti hal-hal rohani. Mereka juga mampu menanggapi tawaran keselamatan yang diberikan Allah di dalam dan melalui Yesus (Mat. 19:14). Yesus juga memakai anak kecil sebagai model / pola bagi orang dewasa mengenai pentingnya kerendahan hati dalam menyikapi Kerajaan Sorga (Mat. 18:2). Doherty mengemukakan bahwa seorang anak sudah dapat menerima Yesus sebagai Tuhan dan Juruselamat pada usia 5 atau 6 tahun. Bagi anak-anak yang diasuh dalam konteks keluarga Kristen, akan lebih siap untuk percaya kepada Yesus pada usia yang lebih muda lagi. (Doherty, 2000, p.21) Mereka telah mampu mengerti hal-hal rohani, kesadaran akan dosa dan menyadari perlunya percaya kepada Yesus demi keampunan segala dosa.

\section{BEBERAPA GAGASAN TENTANG PENDIDIKAN ANAK BALITA}

Diperlukan pemikiran teologis serta strategi untuk memajukan pendidikan anak Balita. Berikut beberapa gagasan bagi perkembangan pendidikan anak Balita dikaitkan dengan tugas pendidikan Kristen di Indonesia.

\section{Keluarga Sebagai Lembaga Pendidikan Anak Balita}

Keluarga adalah lingkungan sosial yang pertama dikenal anak. Itu sebabnya pengaruh orang tua berperan sangat besar bagi anak karena sebagian besar waktu anak adalah bersama ayah, ibu dalam keluarga. Pada masa ini orangtua merupakan orang terpenting bagi anak di samping saudara, kakek dan nenek, pembantu serta teman-teman sepermainan. Segala sesuatu yang dialami dan diajarkan keluarga menjadi fondasi terhadap pembentukan kepribadian, spritualitas anak. 


\section{Orangtua Sebagai Pendidik}

Kedudukan, Peran dan fungsi keluarga, khususnya orangtua sebagai pengajar dan pendidik (guru) sejalan dengan seruan Presiden Megawati dalam pidatonya pada peringatan ke-19 Hari Anak Nasional, 23 Juli 2003. "Pentingnya tanggung jawab orangtua dalam membekali dan menciptakan iklim yang baik kepada anak, sehingga mereka dapat tumbuh dengan baik dan mampu memberi makna bagi kehidupan mereka, keluarga, nusa, dan bangsa". (Media Indonesia, 2003) Paulus dalam surat-surat pastoral yang ditujukan kepada jemaat juga mengungkapkan pentingnya kedudukan, peran dan fungsi orangtua dalam mengajar dan mendidik anak. Ayah yang adalah kepala keluarga yang diberikan tanggung jawab menjadi pemimpin dalam jemaat harus mampu membuktikan bahwa anak-anaknya telah menerima Yesus sebagai Tuhan dan Juruselamat, hidupnya bermoral atau mampu menjadi saksi Yesus (Tit. 1:6).

Pendekatan Pendidikan Kristen yang lebih tepat untuk relasi orangtua dan anak adalah Interpretation atau Penafsiran. Seymour \& Miller menjelaskan bahwa pendekatan tersebut mempelajari keterampilan yang dihubungkan dengan tradisi iman dengan pengalaman hidup sehari-hari dimana guru berfungsi sebagai penunjuk jalan yang memberikan bimbingan. (Seymour \& Miller, 1982, p.28) Kehidupan sehari-hari orangtua sangat efektif dan efisien menjadi wadah bagi anak balita yang belajar hidup dengan menginderai, khususnya "mendengar dan melihat". Contohnya: setelah bangun tidur langsung berdoa, mengucapkan terimakasih kepada suami, isteri atau anak ketika menerima pemberian, mengembalikan benda pada tempat yang seharusnya, meminta maaf pada waktu melakukan kesalahan.

\section{Beberapa Contoh Kasus Keluarga Dalam Alkitab}

Pengaruh didikan yang diterima seorang anak pada masa Balita dibuktikan melalui studi Alkitab beberapa tokoh baik dalam PL maupun PB. Walaupun dalam kurun waktu yang tidak begitu lama, tetapi lima tahun pertama telah dibuktikan melalui kehidupan para tokoh sebagai salah satu penentu kehidupan di masa depan. Fung \& Ming menjelaskan bahwa, "Dalam enam tahun pertama seorang anak terdapat masamasa perubahan dramatis dan merupakan pondasi bagi perkembangan anak di masa yang akan datang" (Fung \& Ming, p.2)

Yusuf, "Penyelamat Israel". Memang Alkitab tidak secara tersurat menjelaskan bahwa Yusuf menerima didikan yang tepat pada usia Balita. Tetapi beberapa indikasi memperlihatkan bahwa pada masa Balita Yusuf memiliki "keuntungan" lebih dibandingkan saudara-saudaranya yang lain. Itu sebabnya di kemudian hari Yusuf bertumbuh menjadi pribadi yang matang.

Latar Belakang Masa Kecil. Latar Belakang Kehidupan Yusuf diawali dari penantian Yakub dan Rahel akan kehadiran seorang anak melalui pernikahan mereka. Yusuf adalah putra ke-11 Yakub dari Rahel isteri terkasihnya (Kej. 30:24; 35:24). Ia menjadi putera kesayangan karena telah lama Yakub menunggu keturunan yang dilahirkan Rahel sendiri (30:22-24). Bukti kasih sayang Yakub ditunjukkan melalui perlakuan istimewanya kepada Yusuf seperti perlindungan melebihi saudaranya (33:2). Ketika Rahel telah meninggal dunia, kasih sayang Yakub tetap ditunjukkan melalui perhatian dan pemberian berbagai jubah indah kepadanya (Kej. 37:3).

Pendidikan Yang Diterima Yusuf Dalam Keluarga. Yusuf menerima beberapa prinsip pendidikan yang diperlukannya sebagai seorang anak. Pendidikan tersebut merupakan salah satu kunci keberhasilannya menghadapi berbagai kesulitan hidup yang 
dihadapi sampai akhirnya Yusuf menjadi orang sukses. Berikut kebutuhan yang diterima Yusuf dalam keluarga:

1. Menerima warisan "Hidup Takut Akan Tuhan"

Sebagai anak bungsu, Yusuf dilahirkan pada saat Yakub sudah matang dengan banyak pengalaman yang menempanya selama di perantauan. Yakub yang pada awalnya berkarakter penipu dengan mengandalkan kelicikannya (Kej. 25:31-34, 27:18) berubah menjadi orang yang belajar terus untuk mengandalkan Allah sebagai Penolong dalam hidupnya (28:20-22). Keputusan Yakub berdampak melalui usahanya yang sungguh-sungguh dengan menunjukkan kejujurannya dalam bekerja selama 20 tahun di rumah Laban pamannya (31:6, 41) sehingga Allah memberkati usahanya (31:42).

Sekalipun tidak dinyatakan secara langsung oleh Alkitab bagaimana Yakub membekali anak-anaknya dalam pengenalan kepada Tuhan, tetapi nyata pada usia dewasa bahwa Yusuf menjalani kehidupannya dengan "takut akan Tuhan". Dapat diperkirakan bagaimana Yakub menceritakan kepada anak-anak dan isterinya tentang Allah Abraham dan Ishak yang juga dipercayai Yakub. Tentu Yakub mengajar keluarganya supaya mereka juga beriman kepada Allah yang sama.

Yusuf membuktikan pengenalannya akan Allah sebagai Pribadi yang hidup dibuktikan melalui keteguhannya melawa godaan dosa seksual (39:9), pengakuan kepada Allah sebagai Sumber hikmat dalam mengartikan mimpi (40:8, 41:16), pemberian nama anak-anaknya dalam bahasa Ibrani yang masing-masing mempunyai arti yang berkaitan dengan Allah sebagai Penolong selama ia hidup di Mesir (41:50-52), kesediaan untuk mengampuni saudara-saudaranya $(45: 3,4)$ serta kepercayaannya terhadap intervensi Allah melalui berbagai kesukaran hidup untuk tujuan yang mulia (50:20).

\section{Mendapatkan Kasih Sayang dan Perhatian Yang Cukup}

Yusuf lahir pada saat-saat terakhir perantauan Yakub di rumah Laban (30:25). Dilihat dari intensitas kesibukan serta tekanan yang dialami, keadaan Yakub jauh lebih baik dibandingkan sebelum Yusuf lahir. Dari segi pendapatan, kekayaan Yakub semakin bertambah bahkan mempunyai banyak budak (30:43). Dengan demikian Yakub mempunyai lebih banyak waktu untuk membagi kasih dengan keluarganya terutama Yusuf sebagai anak bungsu sebelum Benyamin lahir. Sedangkan Rahel masih mempunyai satu anak saja, tentu hal tersebut membuat kebutuhan dasar Yusuf untuk mendapatkan kasih sayang terpenuhi dengan baik. Berdasarkan penjelasan waktu Yakub bekerja di rumah Laban selama 20 tahun untuk mendapatkan Lea, Rahel dan upah bekerja (30:41) kemudian Rahel melahirkan Yusuf dan tidak lama setelah itu Yakub pergi dari rumah Laban, maka kemungkinan besar Yusuf terpenuhi kebutuhan dasarnya akan kasih sayang orangtua serta teladan hidup pada usia Balita.

\section{Bertumbuhnya Karakter Pengampun}

Yakub mempunyai problem keluarga yang beragam karena memiliki dua isteri dan dua gundik. Untuk memperebutkan perhatian Yakub, baik isteri maupun anakanaknya berkompetisi sehingga terpupuklah sifat iri satu dengan yang lain. Tetapi bagi Yusuf yang menerima kasih sayang penuh dari orangtuanya sejak kecil, justru sifat mengampuni yang dominan berkembang dalam dirinya. Hal itu telah dibuktikan ketika Yusuf menjadi raja, dia tidak mengungkit kejahatan saudara-saudaranya melainkan mengampuni dan mengasihi mereka dengan ketulusan (45:4-5) serta melihat secara positif bahwa perlakuan saudara-saudaranya dipakai oleh Allah untuk merencanakan keselamatan bagi keturunan Israel dari kelaparan (50:20). 
Musa, Pemimpin Besar. Kehidupan Musa sebagai tokoh besar dalam sejarah bangsa Israel menjadi salah satu bahan kajian terhadap sebuah prinsip dalam ranah pendidikan anak usia balita (dini). Beberapa tahap dalam perkembangan hidupnya sampai Musa muncul sebagai pemimpin yang berkenan di hadapan Tuhan tidak dapat dilepaskan dari kehidupan masa kecilnya bersama dengan orangtua (Kel. 1:16; Kel. 6:19; Ibr. 11:23). Hal-hal penting yang dialami Musa pada masa balita yang membawa pengaruh bagi hidupnya:

\section{Pentingnya Kedekatan Anak dengan Orangtua}

Menjadi ketakutan tersendiri bagi keluarga Israel yang melahirkan bayi laki-laki. Sekalipun berupaya menyelamatkan anak mereka, suatu saat pegawai Firaun dapat menemukan dan membunuhnya. Kecemasan yang dialami orangtua Musa secara psikologis pasti juga mempengaruhi ketenangan Musa yang saat itu dapat bertahan di rumah sampai dengan usia tiga bulan (Kel. 2:2). Tetapi setelah Musa dibuang dan dipelihara kembali oleh orangtuanya, ia tetap merasakan perlindungan karena terpeliharanya relasi orangtua dengan anak yang mendatangkan rasa aman. Pengalaman tersebut mempengaruhi pribadi Musa dikemudian hari. Ketika Allah mempercayakannya sebagai pemimpin Israel, Musa mempunyai relasi yang sangat akrab dengan Allah melebihi nabi-nabi lainnya (Bil. 12:7-8). Selain itu Musa menjadi orang yang tidak mudah panik atau ketakutan menghadapi masalah. Sebaliknya, Allah mengakui keberadaan Musa sebagai orang yang paling sabar dengan hati yang penuh kelembutan (Bil. 12:3). Beberapa kali bangsa Israel mengalami kesukaran kemudian mereka mulai mengatai Musa dan menuntut pertolongan Allah, Musa tetap tenang dan membawa mereka berharap kepada Allah (Kel. 14:13-14). Kedekatan Musa dengan orangtua pada masa kecil menumbuhkan kepercayaannya terhadap Allah sebagai Pelindung sejati.

\section{Pengenalan Diri Dimulai Dari Keluarga}

Keyakinan orangtua Musa terhadap rencana Allah mengakibatkan mereka memutuskan untuk membuang Musa ke sungai dengan harapan puteri Firaun akan menemukan dan mengambil Musa sebagai anak. Harapan itu menjadi kenyataan dimana Musa kemudian diasuh kembali oleh orangtuanya sendiri selama masa menyusui (2:9). F.L. Bakker dalam Sejarah Kerajaan Allah (1993, p.256) menjelaskan bahwa berdasarkan tradisi pada jaman itu, anak disapih sesudah berumur tiga sampai empat tahun. Setelah masa menyusui selesai, maka Musa diserahkan kepada puteri Firaun untuk dididik dan dibesarkan di istana Mesir.

Sebuah kenyataan yang tidak dapat dipungkiri bahwa waktu yang tidak terlalu lama kebersamaan dengan keluarga, mempunyai pengaruh besar dalam kehidupan Musa. Pengalaman Musa adalah salah satu dari beberapa contoh dalam Alkitab yang membuktikan bahwa pada usia Balita seorang anak mampu merekam setiap pengetahuan maupun pengalaman hidupnya. Tentu orangtua Musa menanamkan ajaran iman kepadanya sehingga Musa mengenal Allah. Begitu juga keputusannya untuk membela bangsa Israel yang tertindas serta kepergiannya dari Mesir merupakan pengaruh dari pengenalan Musa terhadap diri dan keluarganya sebagai umat pilihan Allah.

\section{Prinsip Pendidikan Melalui Percontohan Keluarga Imam Eli}

Satu prinsip yang paling berpengaruh dalam pembelajaran kepada anak balita ialah melalui percontohan (keteladanan) orangtua. Prinsip ini lebih kuat pengaruhnya dibandingkan dengan pendidikan yang bersifat kognitif, disebabkan anak melihat atau 
mendengar langsung keteladanan orangtua dalam mengatasi pelbagai masalah. Anak juga hendak membuktikan apakah tindakan orangtua bersesuaian dengan ajaran dan didikan yang disampaikannya kepada anak.

Berdasarkan metode Pendidikan yang dijelaskan oleh Pazmino, percontohan merupakan bukti bahwa orangtua selaku pengajar tidak sekedar menyampaikan pengetahuan. Seperti yang diperbuat Yesus sebagai Guru Agung (The Master Teacher), salah satu metode pengajaran yang diaplikasikan adalah menghidupi ajaran-Nya. (Pazmino, 2012, p.128) Yesus tidak sekedar mengajar dan mendidik mengenai pengampunan, namun Ia sendiri menghidupi ajaran-Nya lewat doa pengampunan yang diberikan-Nya kepada orang-orang yang menyalibkan Dia (Luk. 23:34).

\section{Melihat Model Yang Salah}

Kasus yang terjadi dalam kehidupan keluarga imam Eli menarik dan relevan untuk diangkat sebagai pembahasan terhadap pendidikan anak balita. Hal ini disebabkan pengalaman keluarga imam Eli membawa pengaruh terhadap perkembangan Samuel. Samuel tinggal bersama dengan imam Eli di Silo setelah Hana menyerahkan Samuel menjadi hamba Tuhan melalui pengasuhan imam Eli.

Sebagai senior dalam dunia pelayanan, pasti imam Eli mengajar dan mendidik Samuel dalam pelbagai pengetahuan, pemahaman dan pengalaman mengenai bagaimana menjadi seorang pelayan Tuhan. Imam Eli berhasil mengasuh Samuel karena pada akhirnya Samuel bertumbuh dan berkembang menjadi anak yang hidup akrab dengan Tuhan. Pertumbuhan iman Samuel menjadikannya seorang yang semakin disukai oleh manusia dan Allah (1 Sam. 2:26). Hal ini membuktikan bahwa Samuel memiliki mutu hidup yang pantas dipercayakan sebagai pemimpin di masa yang akan datang. Nampak jelas bahwa Samuel dapat melakukan tugas dan tanggung jawab dengan baik selama melayani sebagai nabi, imam maupun hakim. Ia menjadi hamba Allah yang tegas menegakkan kebenaran, hormat kepada Tuhan dan setia dalam kehidupan doanya (1 Sam. 12:23). Karena itu, ketika Samuel meninggal, bangsa Israel meratapinya karena sangat kehilangan (1 Sam. 25:1).

Pada sisi lain kehidupan imam Eli yang selanjutnya juga berpengaruh dalam kehidupan Samuel adalah kegagalannya dalam melakukan pendidikan di tengah keluarga. Apa yang terjadi dalam kehidupan imam Eli di kemudian hari terjadi juga dalam kehidupan rumah tangga Samuel. Meskipun tidak separah anak-anak Eli, salah satu alasan mengapa bangsa Israel meminta raja adalah karena anak-anak Samuel tidak hidup seperti Samuel (1 Sam. 8:5). Samuel membutuhkan model yang dapat memberikan konsep sebuah keluarga dan peran, fungsi orangtua sebagai pengajar dan pendidik terhadap anak-anaknya. Kemungkinan juga apa yang diperbuat Eli dalam menegur anak-anaknya juga dicontoh oleh Samuel sehingga meskipun Samuel tegas terhadap orang lain namun tidak bagi anak-anaknya.

\section{Anak Tanpa Disiplin}

Sebagai imam yang juga merupakan kepala keluarga, Eli tidak mampu mengaplikasikan disiplin bagi anak-anaknya. Segala kejahatan yang didemontrasikan anak-anak imam Eli tidak ditindak tegas, namun hanya memberikan teguran saja (1 Sam. 2:23-25), padahal dalam peraturan keimaman idealnya mereka dikucilkan dari jabatannya sebagai imam. Akibatnya mereka tidak memiliki rasa hormat kepada Eli bahkan mempermalukan keluarga Eli. Haye memaparkan bahwa disiplin merupakan bagian dari sifat yang dibangun orangtua dalam diri anak yang akan memberi jalan kehidupan kepada anak dimana disiplin tersebut menjadi efektif bila berjalan bersama kasih. (La Haye, 1997, p.187) Kitab Amsal banyak membahas prinsip Alkitab dalam 
mendisiplin anak sebagai tindakan mengajar dan mendidik demi kebaikan anak (Ams. $3: 18 ; 6: 20-23)$.

\section{Pendidikan Keluarga Timotius}

Tokoh dalam Perjanjian Baru yang terkenal dengan kehidupan salehnya sebagai orang muda ialah Timotius. Pertumbuhan iman yang nyata serta keberhasilannya dalam pelayanan tidak dapat dilepaskan dari latar belakang keluarganya yang telah memperlengkapi Timotius dengan nilai-nilai rohani.

\section{Peran Orang-orang Dekat}

Keterangan yang menonjol dari kehidupan Timotius pada masa kecil ialah didikan orangtua khususnya ibu dan nenek Timotius dalam usaha memperkenalkan Allah kepada Timotius (II Tim. 1:5). Dalam kehidupan Timotius jelas bahwa iman orangtua mempengaruhi pertumbuhan iman anak. Orangtualah yang pertama sekali bertugas membawa anak kepada Allah dan hal itu telah dilaksanakan Eunike melalui keteladanan hidup berimannya. Eunike sendiri meneladani Lois sebagai ibu yang telah berhasil menanamkan ajaran iman kepada anaknya.

\section{Pengenalan Akan Allah Pada Masa Anak}

Selain percontohan melalui kehidupan sehari-hari, Timotius juga mendapatkan ajaran tentang Allah melalui Kitab Suci yang telah dikenalnya sejak kecil (II Tim. 2:15). Melaluinya Timotius menerima hikmat serta tuntunan yang membawanya percaya kepada Tuhan Yesus sebagai Juruselamat.

\section{Ragam Masalah Keluarga Raja Daud}

Raja Daud menjadi tokoh yang banyak disebut dalam Alkitab. Demikian juga pada waktu Yesus lahir dan hidup di dunia, Daud menjadi tokoh tipologi Tuhan Yesus yang penggenapannya terjadi ketika Yesus datang (Mat. 1:1, 20; Luk. 1:32; Yoh. 7:42). Pasti banyak alasan yang melatarbelakangi mengapa Daud menjadi tokoh besar yang patut menjadi teladan terhadap umat Allah. Sebagai pemimpin bangsa, Daud berhasil dalam pelbagai bidang. Namun, penting untuk melihat lebih dalam kehidupan keluarga Daud sebagai bahan kajian untuk melihat model setiap keluarga dalam melaksanakan pendidikan di tengah keluarga.

\section{Keteladanan Dalam Hidup Takut Akan Tuhan}

Daud mempunyai sikap hati yang sangat baik dalam hubungannya dengan Allah. Ia merupakan orang yang tulus dan sangat mengasihi Tuhan. Keseriusannya dalam mengasihi Tuhan nampak jelas melalui ungkapan-ungkapan dan tindakannya yang diterima dan diakui oleh Tuhan dan manusia. Daud tidak bisa menerima ejekan Goliat dan tentara Filistin yang menghina Allah (1 Sam. 17:26, 45). Daud berupaya menjauhi dosa untuk membunuh Saul karena menyadari bahwa ia tidak berhak melakukan pembalasan (1 Sam. 24:11, 13). Dalam pelbagai pengalaman hidup baik yang menyukakan atau menyedihkan hatinya, sukacita atau dukacita, senantiasa disampaikan Daud kepada Allah melalui berbagai Mazmur sebagai bukti penyerahan hidupnya kepada Allah. Cinta kasihnya kepada Tuhan nyata dari keinginannya yang kuat untuk membangun rumah Tuhan (2 Sam. 7:2). Sikap takut akan Tuhan yang dimiliki Daud menjadi landasan bagi Tuhan untuk mengukur kesetiaan raja-raja Yehuda selanjutnya. Sikap Daud sebagai pemimpin bangsa dan kepala keluarga juga mempengaruhi kehidupan dan perkembangan kerohanian anak-anaknya. Misalnya, kehidupan iman 
Salomo sebagai raja yang memerintah dengan hidup takut akan Tuhan sehingga Allah memberkati pemerintahan Salomo (I Raj. 10:14-29).

\section{Poligami Merusak Kesatuan Keluarga}

Salah satu kegagalan Daud dalam mengajar dan mendidik anak-anaknya diakibatkan oleh keteladanan yang tidak baik dalam membentuk rumah tangga. Sama seperti raja-raja pada umumnya, Daud juga terjebak dalam pernikahan poligami (1 Sam. 18:27; 1 Sam. 25:43; 1 Sam. 25:42; 2 Sam. 3:3; 2 Sam. 3:4; 2 Sam. 3:4-5; 2 Sam. 11; 1 Taw. 3:6-9. Pernikahan poligami Daud mengakibatkan kekacauan dalam rumah tangganya. Sebagian dari isterinya menikah dengan Daud pada waktu Daud melarikan diri dari Saul. Dalam pelarian tersebut anak-anak Daud lahir dan bertumbuh. Seperti yang terjadi pada keluarga Yakub, para isteri dan anak-anak Daud pun bersaing untuk memperebutkan perhatian Daud. Kompetisi mereka juga terlihat pada masa tua Daud dimana Adonia berupaya memperebutkan kursi kerajaan dari Salomo (1 Raj. 1). Sedangkan Poligami yang dilakukan Daud mempengaruhi kehidupan Salomo di masa depan. Meskipun menjadi raja yang sangat berhikmat, Salomo tidak memberikan contoh yang baik dalam pernikahan dengan mempunyai 700 isteri dan 300 gundik (1 Raj. 11:3). Akhirnya Salomo tidak setia beribadah kepada Tuhan, namun menyembah ilah para isterinya.

3. Hilangnya Wibawa Akibat Perselingkuhan

Kasus sangat berat yang dialami Daud dalam masa pemerintahannya adalah pemberontakan anaknya sendiri, Absalom. Kejahatan yang dilakukan Absalom untuk menggulingkan pemerintahan Daud disertai dengan perkosaan terhadap para gundik Daud (2 Sam. 16:22). Begitu juga tindakan perkosaan Amnon terhadap Tamar secara tidak langsung merupakan akibat dari perselingkuhan yang dilakukan Daud terhadap Batsyeba (2 Sam. 11).

\section{Pendidikan Bagi Pengasuh Anak atau Babby Sitter}

Berdasarkan nasihat rasul Paulus kepada Timotius, dapat disimpulkan bahwa tugas pembelajaran mempunyai tujuan agar murid "menjadi orang yang dapat dipercayai, yang juga cakap mengajar orang lain" (2 Tim. 2:2). Penjelasan tersebut menunjuk kepada panggilan mengajar sebagai salah satu panggilan mulia yang diberikan Allah untuk memuridkan orang lain menjadi pengajar.

Bagi sebagian besar anak yang tinggal di kota, Babby Sitter yang bertugas menjaga anak selama waktu tertentu atau pengasuh anak parowaktu atau sepenuh waktu, mengambil bagian yang penting dalam pendidikan anak. Hal tersebut dikarenakan kebanyakan orangtua bekerja sehingga memiliki kesempatan yang terbatas untuk merawat anak. Dalam hal ini orangtua dapat bekerjasama untuk menghasilkan pola pendidikan yang baik bagi anak. Dalam kerjasama tersebut, Sylvia Rimm menjelaskan bahwa orangtua perlu memberitahukan bentuk pola asuh yang diterapkan kepada si pengasuh dan menghargai profesionalisme serta keterampilan yang dimiliki pengasuh. (Rimm, 2003, p.125)

Lembaga Kristen baik gereja maupun lembaga sosial lainnya dapat menggumuli masalah pengasuh anak sebagai pokok yang penting untuk dikelola. Menerapkan prinsip Paulus, orangtua dapat membekali para pengasuh anak dengan berbagai keterampilan khususnya bekal rohani yang memampukan para pengasuh menjadi pengajar bagi anakanak yang dipercayakan kepada mereka. Gereja bekerjasama dengan orangtua dapat mendirikan semacam training atau penyedia jasa para pengasuh yang dididik iman dan keterampilannya. 


\section{Pendidikan Anak Balita Di Sekolah}

Selain keluarga, anak mulai berkenalan dengan lingkungan sosial yang lebih luas lagi yaitu sekolah. Sylvia Rimm menjelaskan, "Anak umur tiga tahun biasanya siap masuk prasekolah, asalkan program yang disusun disesuaikan dengan kebutuhan anak". (Rimm, 2003, p.119) Orang-orang yang berpengaruh bagi anak di sekolah ialah Guru dan Teman.

\section{Pengaruh Guru di Sekolah Bagi Anak Balita}

Salah satu unsur penting dalam pendidikan anak Balita ialah guru sebagai pendidik. "Pendidikan dan Pendidik" adalah dua kunci yang memegang peranan penting bagi kelangsungan sejarah dan kualitas hidup manusia. Stephen Tong mengungkapkan," Berlangsungnya sejarah berada di tangan mereka yang mendidik seorang anak. Jikalau kita menyerahkan seorang anak kepada seorang pendidik yang tidak mengetahui pendidikan secara tepat dan tidak seharusnya menjadi pendidik, maka kita telah menyerahkan harta kita yang paling berharga kepada orang asing, yang kita tidak tahu akan dijadikan apa anak kita nantinya". (Tong, 2008, p.33)

Dengan demikian jelas bahwa anak Balita membutuhkan Pendidik dan Pendidikan yang tepat. Kesalahan dalam proses pendidikan yang dialami anak sama halnya dengan kehilangan sebuah kesempatan yang tidak mungkin diulang kembali untuk memperbaikinya karena segala sesuatu yang diterima anak menjadi bekal bagi masa depannya. Burgess (1975, pp.41-44) mengusulkan beberapa kriteria guru berdasarkan pendekatan tradisional bagi pendidikan rohani

a. Kualifikasi pertama yang harus ada pada guru ialah imannya kepada Allah.

b. Sangat penting bagi seorang guru untuk memiliki karakter Kristen yang menunjukkan kualitas pribadinya

c. Mengikuti berbagai pelatihan agar memiliki kemampuan terhadap studi Alkitab, psikologi maupun tehnik mengajar.

Nainggolan, Daeli, Simanjuntak menambahkan bahwa dalam konteks sekolah seorang guru Kristen haruslah memiliki kompetensi pedagogik, kepribadian, sosial, profesional dan spritualitas. Guru-guru dipanggil untuk menjadi serupa dengan Kristus. (Nainggolan \& Daeli, 2021, pp.33-48) Bagi pendidikan formal anak Balita di Indonesia , peranan guru dalam mendidik anak dapat dilaksanakan melalui Play Group dan Taman Kanak-kanak. Anak akan dapat menikmati kehidupan di sekolah bukan hanya pengaruh dari sarana atau kurikulum yang menarik melainkan peran guru yang dapat mengambil hati anak melalui pribadi yang penuh kasih. Stephen Tong menetapkan kualifikasi guru yaitu sudah dilahirkan kembali, memiliki watak Kristen dan kepribadian yang Alkitabiah, mempunyai pengetahuan akan kebenaran serta bertanggung jawab dalam mendidik. Disamping itu ada kualifikasi tambahan yang merupakan pendukung praktis yaitu mencintai dan mau mengerti murid, membangkitkan niat juang dan bersifat adil pada murid. (Tong, 2008, p.30)

Pergaulan Dengan Teman-teman

Beverly La Haye mengidentifikasi salah satu sikap anak ketika masuk sekolah pada hari-hari pertama ialah mengalami kegelisahan karena berpisah dengan ibunya sehingga merasa takut. "Anak merasa takut sebab guru dan anak-anak lain adalah orang-orang asing". (La Haye, 1997, p.110) Menyikapi masalah pergaulan anak dalam interaksi dengan teman-temannya, orangtua berperan besar mengarahkan anak untuk 
ikut terlibat dalam berbagai kegiatan dengan anak-anak lain. Pemilihan teman yang tepat membantu perkembangan anak menumbuhkan nilai hidup yang baik (I Kor. $15: 33)$.

\section{Pelayanan Gereja Bagi Anak Balita}

Beberapa tanggung jawab gereja dalam penyelenggaraan pendidikan anak Balita dapat dilaksanakan melalui jalur pembinaan orangtua maupun penyelenggaraan Sekolah Minggu dengan penyusunan kurikulumnya.

Pendidikan Anak Balita Melalui Pelayanan Sekolah Minggu

Pendidikan Kristen bagi anak Balita tidak dapat dilepaskan dari Sekolah Minggu karena banyak gereja yang telah menyelenggarakan kebaktian mulai kelas Balita maupun Batita (bawah tiga tahun). Richards menjelaskan bahwa pendidikan bagi anak prasekolah memang penting dinyatakan melalui perbuatan dan teladan hidup guru, tetapi kebenaran Kristen harus disampaikan dengan kata-kata. (Richard, 1994, p.209) Untuk mengenal kebenaran, Firman Allah harus diterangkan dengan sederhana melalui bahasa yang dapat difahami oleh anak-anak kecil. Dengan demikian pelayanan bagi anak Balita dalam kebaktian Sekolah Minggu harus selalu ada penjelasan Firman Tuhan.

Banyak para teolog yang tidak setuju dengan metode tersebut, tetapi dengan mengingat pernyataan Allah bahwa setiap firman yang keluar dari mulut Allah tidak akan pernah kembali dengan sia-sia melainkan melaksanakan kehendak Allah (Yes. 56:11), maka kita meyakini bahwa Roh Kudus sanggup menterjemahkan firman itu ke dalam hati anak-anak. Mereka akan memahami dan kemudian dimampukan oleh pertolongan Roh Kudus untuk melakukan firman yang diketahuinya dalam kehidupan sehari-hari.

Penyusunan Kurikulum Sekolah Minggu Bagi Anak Balita

Memperhatikan karakteristik anak Balita yang disampaikan Michelle Anthony dari berbagai aspek perkembangan serta implikasinya bagi pelayanan seharusnya kurikulum Sekolah Minggu disusun secara proporsional antara pemenuhan terhadap kebutuhan rohani dengan psikologis. (Anthony, 2001, pp.208-2010) Berkaitan dengan salah satu kasus yang tercatat dalam deskripsi masalah, banyak guru Sekolah Minggu stres karena anak susah untuk konsentrasi. Pada saat berlangsung kebaktian sampai dengan selesai, anak tidak mau berhenti bergerak dan berjalan. Dengan mempertimbangkan bahwa secara psikologis anak menjalani tahap perkembangan psikomotorik yang menggemari permainan dan gerak untuk melatih otot-otot tubuh.

Gereja perlu memperhatikan berbagai aspek dalam penyusunan kurikulum bagi pelayanan anak Balita. Richards menekankan pentingnya kurikulum yang disusun dengan baik sangat bermanfaat untuk menolong terselenggaranya proses belajar mengajar. Tetapi guru harus berprinsip bahwa kurikulum hanyalah alat bantu sedangkan otoritas tertinggi ada pada Alkitalah. (Richard, 1994, p.193)

Berdasarkan pengamatan team Persekutuan Evangelisasi Anak Jakarta yang menangani pembinaan Sekolah Minggu di berbagai denominasi gereja, kurikulum Sekolah Minggu yang tecatat dalam buku penuntun pelajaran tiap gereja kebanyakan menekankan kepada aspek kognitif saja. Sementara itu kebutuhan bagi perkembangan psikomotorik anak sangat dibatasi. Guru misalnya lebih senang melihat anaknya duduk diam dan mendengarkan cerita dengan baik sebagai bukti bahwa anak serius mengikuti 
kebaktian. Salah satu muatan kurikulum bagi anak Balita yang perlu dipikirkan oleh gereja ialah menyampaikan pesan Alkitab melalui permainan dan pujian.

\section{Cerita Sebagai Salah Satu Metode Pembelajaran}

Sebagai Guru Agung, Tuhan Yesus mengajar dengan kreatif melalui berbagai macam metode. Pazmino mengemukakan bahwa salah satu metode yang sering dipergunakan Tuhan Yesus ialah mengajar dengan bercerita melalui perumpamaan (2001:71). Dalam Perjanjian Lama, Alkitab mencatat beberapa perintah mengenai pendidikan yang disampaikan melalui cerita. Shema sebagai dasar pendidikan keluarga Yahudi menjelaskan bahwa perintah untuk mengasihi Allah harus disampaikan berulang-ulang kepada anak cucu (Ul. 6:1-9). Tentu para orangtua akan menceritakan pemeliharaan Allah melalui berbagai mujizat sepanjang sejarah perjalanan bangsa Israel di padang gurun kepada anak-anak. Ketika Yosua memimpin bangsa Israel menyeberangi sungai Yordan, didirikanlah 12 batu peringatan agar mereka dapat menceritakan perbuatan Tuhan yang besar kepada anak-anak (Yos. 4:21-14).

Melalui mazmur pujian, raja Daud juga mengajak setiap generasi menceritakan keperkasaan Tuhan melalui pekerjaan-pekerjaan-Nya kepada angkatan demi angkatan (Maz. 145:4). Sam Doherty sebagai pendidik dan penginjil yang terpanggil khusus untuk melayani anak-anak menjelaskan bahwa, "cara terbaik untuk mengajarkan dokrin Alkitab kepada anak-anak ialah melalui cerita seperti yang biasanya dipakai untuk menyampaikan firman Allah kepada mereka”. (Doherty, 1999, p.29) Richard melihat berdasarkan filsafat pendidikan bahwa, "pendekatan dasar yang digunakan untuk mengajar anak-anak kecil adalah dengan jalan bercerita". (Richards, 1994, p.273) Metode itulah yang efektif perasaan anak sehingga anak mengalami dan mengambil keputusan untuk meresponi cerita. Richard juga menambahkan bahwa untuk anak usia dua sampai tiga tahun aktifitas adalah media komunikasi yang lebih baik dibandingkan cerita. Tetapi karena kebenaran harus tetap disampaikan maka firman Tuhan dapat diceritakan semenarik mungkin dengan berbagai alat peraga sebagai alat bantu.

\section{Pentingnya Lingkungan Bagi Pertumbuhan Iman Mengingat Anak Masih Labil}

Ditinjau dari segi psikologis, anak Balita berada pada tahap awal dari masa perkembangan hidup manusia. Ia masih labil dan membutuhkan orang lain sebagai penolong baginya agar terus berkembang sebagai pribadi yang bertumbuh dewasa. Erikson berpendapat bahwa lingkungan sosial sangat berperan dalam pembentukan kepribadian seseorang. Pada usia Balita anak sedang berlatih mengembangkan rasa percaya terhadap orang lain, mengembangkan sikap otonomi serta inisiatif. (Wilhoit et al, 1995, p.97)

Mempertimbangkan pengaruh dari beberapa faktor tersebut, keluarga sebagai lingkungan pertama yang dikenal anak punya peran penting mengisi lima tahun pertama dalam kehidupan anak dengan pendidikan yang berarti. Berdasarkan Tiga Sistem Bentuk Pendidikan menurut Pazmino, keluarga dapat dikategorikan sebagai lembaga yang melaksanakan Pendidikan Informal dimana pembelajaran dilaksanakan berdasarkan kehidupan dan pengalaman. (Pazmino, 1992, p.63) Mengkolaborasikan Pendidikan Kristen dengan Perkembangan Psikologi berdasarkan penjelasan Pazmino maka tugas-tugas spiritual untuk anak usia Balita antara lain: Pertama, pengalaman kasih, rasa aman, disiplin, rasa senang dan ibadah. Kedua, mengembangkan kesadaran konsep tentang Allah, Tuhan Yesus serta kehidupan Kristen. Ketiga, menumbuhkan 
sikap terhadap Allah, Tuhan Yesus, gereja, diri sendiri dan Alkitab. Keempat, mulai menumbuhkan konsep benar dan salah. (Pazmino, 2012, p.211)

\section{SIMPULAN DAN SARAN}

Sama seperti manusia dewasa, anak Balita juga membutuhkan pendidikan. Pendidikan bagi kelompok usia Balita sangat penting karena akan mempengaruhi perkembangan seluruh aspek hidupnya di kemudian hari. Pendidikan Kristen berperan penting mengisi masa Balita dengan pengetahuan dan pengalaman hidup yang berarti dalam membekali diri bagi masa depannya. Selain gereja dan sekolah, keluarga khususnya orangtua merupakan guru terpenting bagi anak. Dapat disimpulkan bahwa seluruh pendidikan yang dilaksanakan bertujuan mengajar anak-anak untuk hidup takut akan Tuhan, berjalan dalam kehendak-Nya, mengasihi Dia serta melayani dengan segenap hati dan jiwa. (Ef. 6:4; Ul. 10:2).

Dalam teori dan praktik pendidikan Kristen bagi anak balita dalam pelbagai konteks penting untuk memahami bahwa tahap-tahap perkembangan anak balita berbeda dengan orang dewasa, memahami prinsip-prinsip pembelajaran anak balita agar pembelajaran efektif, anak balita memiliki hak yang sama untuk mengenal Yesus dalam hidupnya agar terbebas dari maut, anak balita perlu mendapat pengajaran dan pendidikan sesuai dengan tugas, peran, kebutuhan dan tanggung jawab mereka di lingkungannya, metode yang dipilih haruslah kreatif dan inovatif, yang sesuai dengan kondisi anak balita. Pesan Alkitab dan teologi Kristen patut menjadi inspirasi dan motivasi bagi mereka yang terlibat dalam pelayanan anak dalam pelbagai konteks (keluarga, sekolah, gereja, masyarakat) untuk memandang pendidikan anak balita adalah hal yang sangat signifikan dan mendesak; perlu mendapat perhatian yang sungguh-sungguh, sadar, terencana dan berkesinambungan. Anak balita yang memperoleh pendidikan Kristen yang berkualitas akan menghasilkan pribadi yang unggul. Akhirnya, patutlah pendidikan Kristen bagi anak balita dalam pelbagai konteks direncanakan, dilaksanakan dan dievaluasi dengan baik pada setiap tahapan perkembangannya, karena usia tersebut adalah masa yang terpenting dan menentukan dalam sejarah perjalanan manusia di dunia.

\section{DAFTAR PUSTAKA}

Daeli Adventrianis, Nainggolan, Alon Mandimpu (2020). Persepsi Jean Charlier De Gerson dan Tuhan Yesus Kristus Mengenai Pendidikan Agama Kristen Anak. Montessori: Jurnal Pendidikan Kristen Anak Usia Dini. Vol. 1 No. 2, h. 45-57. https://ejournal-iakn-manado.ac.id/index.php/montessori/article/view/496/360.

Ismail, Andar (2015). Ajarlah Mereka Melakukan: Kumpulan Karangan Seputar Pendidikan Agama Kristen. Jakarta: BPK Gunung Mulia.

Nainggolan, Alon Mandimpu, Yanice Janis. Etika Guru Agama Kristen Dan Relevansinya Terhadap Pendidikan Iman Naradidik. https://ojs.sttibc.ac.id/index.php/ibc/article/view/23/22. https://doi.org/10.46348/car.v1i2.23. CARAKA: Jurnal Teologi Biblika dan Praktika. Vol. 1 no 20 tahun 2020.

Nainggolan, Alon Mandimpu, Labobar Feni Yuni (2021). Menggagas Penggunaan Benih dalam Perayaan Paskah: Analisis Biblikal Yohanes 12:20-26. Epigraphe: Jurnal Teologi dan Pelayanan Kristiani. Vol. 5 No. 1, h. 113-125. 
http://www.stttorsina.ac.id/jurnal/index.php/epigraphe/article/view/239. http://dx.doi.org/10.33991/epigraphe.v5i1.239.

Nainggolan Alon Mandimpu Nainggolan, Daeli Adventrianis, Simanjuntak, David Rade Manat. Persepsi Calon Guru Pendidikan Agama Kristen (PAK) Tentang Belas Kasihan dalam Profesi Keguruan. Didaskalia: Pendidikan Agama Kristen, Vol. 2 No. 1 (2021). $\quad$ h. 33-48. https://ejournal-iaknmanado.ac.id/index.php/didaskalia/article/view/518.

Pazmino, W. Robert (2001). God Our Teacher: Theological Basics in Christian Education. Baker Academic.

Pazmino, W. Robert (2012). Fondasi Pendidikan Kristen. Jakarta: BPK Gunung Mulia.

Richards, Lawrance O. (1994). Mengajarkan Alkitab Secara Kreatif. Bandung: Yayasan Kalam Hidup, 1994.

Singgih D. Gunarsa (2000), Psikologi Perkembangan Anak dan Remaja, (Jakarta: PT Gunung Mulia.

Sugiyono (2011). Metode Penelitian Kualitatif, Kuantitatif, Kombinasi Bandung: Alfa Beta.

Tong, Stephen (2008). Arsitek Jiwa II. Surabaya: Momentum.

Wilhoit, C James \& Dettoni, M. John (1995). Nurture That Is Christian. America: Zondervan Publishing House. 